\title{
Late Bloomer: The Gentian as Sign or Symbol in the Work of Dickinson and Her Contemporaries
}

\author{
Elizabeth A. Petrino \\ Fairfield University, epetrino@fairfield.edu
}

Follow this and additional works at: https://digitalcommons.fairfield.edu/english-facultypubs

Copyright 2005 by The Johns Hopkins University Press for Emily Dickinson International Society (EDIS)

\section{Peer Reviewed}

\section{Repository Citation}

Petrino, Elizabeth A., "Late Bloomer: The Gentian as Sign or Symbol in the Work of Dickinson and Her Contemporaries" (2005). English Faculty Publications. 72.

https://digitalcommons.fairfield.edu/english-facultypubs/72

\section{Published Citation}

Petrino, Elizabeth A. "Late Bloomer: The Gentian as Sign or Symbol in the Work of Dickinson and Her Contemporaries." The Emily Dickinson Journal 14, no. 1 (2005): 104-125.

This item has been accepted for inclusion in DigitalCommons@Fairfield by an authorized administrator of DigitalCommons@Fairfield. It is brought to you by DigitalCommons@Fairfield with permission from the rightsholder(s) and is protected by copyright and/or related rights. You are free to use this item in any way that is permitted by the copyright and related rights legislation that applies to your use. For other uses, you need to obtain permission from the rights-holder(s) directly, unless additional rights are indicated by a Creative Commons license in the record and/or on the work itself. For more information, please contact digitalcommons@fairfield.edu. 


\section{ELIZABETH A. PETRINO}

\section{Late Bloomer: The Gentian as Sign or Symbol in the Work of Dickinson and Her Contemporaries}

7 setts, holds a small volume of William Cullen Bryant's "To the Fringed Gentian." Decorated with a medallion depicting the poet's head wreathed in blue gentians, the cover neatly uses the ubiquitous, humble flower, known as a herbal remedy since ancient times to confer the poetic immortality of Apollo's laurel wreath. ${ }^{1}$ Bryant's poem suggests that the gentian reminds readers of the moral development that will lead to their spiritual ascent. Within the volume, the illustrations sum up the spiritual life the flower was thought to emblematize: the first depicts the author discovering it on a ramble through the woods; in the second, he strolls by a brook where it grows; in the third, on his deathbed, he grasps it and looks up at a rainbow through an open window. These pictures reaffirm the flower's spiritual qualities as does the book's design: a fringe of light blue material glued to its margins conflates the volume with the flower.

The tendency among scientists and poets of Emily Dickinson's generation to see nature as an emblem of spiritual life clarifies, by contrast, Dickinson's departure from a standard botanical convention. An emblem represents something else; a pictorial symbol or allegorical picture inscribed with a verse or motto frequently teaches a moral lesson. William Cullen Bryant and John Greenleaf Whittier often incorporate in their poems sanctioned emblems and religious references that were well understood by nineteenth-century American culture. Their poems were excerptable and, thus, became widely known, partly because they were exponents of a conservative worldview meant to instruct its readership. They also assume the supposed transparency between nature and spiritual life that sometimes amused 
and sometimes troubled the more original Dickinson. I believe her use of flowers was more fluid, flexible, and dynamic than the received tradition of religious and spiritual literature allowed. ${ }^{2}$ Her botanical reading illustrates how she veered away from the age's religiocentrism, with its attendant attitudes toward gender.

Among the many flowers to which she refers, the gentian seems a literary one: not mentioned in the Bible, it gathered cultural significance through literary use. In several poems alluding to this late summer to early fall flower, Dickinson portrays herself as an artist who writes under extreme conditions. Her choice of the gentian is especially intriguing when one considers that she was actively compiling her poems into notebooks during the period when several of these lyrics were written. Beginning around 1858 and ending around 1863 or 1864, Dickinson transcribed her poems, including three on the gentian, into manuscript books and later on sets of loose sheets until about 1877, when she gave up the practice altogether. Placed prominently at the beginning of her first fascicle, two poems, "The Gentian weaves her fringes" (Fr21) and "Distrustful of the gentian" (Fr26) raise interesting questions about the status, as Mary Loeffelholz observes, of "the book and bookmaking" (61). ${ }^{3}$ Immersed in the selecting and ordering of her poems, Dickinson might have adopted the gentian, a late-blooming flower, to comment on her literary peers and as a metaphor for her own evolving literary career. Her early botanical education at Mount Holyoke Seminary encouraged close observation of nature and offered an important type of artistic production outside publication - namely, herbaria. Dickinson's awareness of the intimate connection between women and flowers began early with her studies in botany and the construction of her extant herbarium. Whereas for her poetic contemporaries, like Bryant and Whittier, the gentian symbolized the humility that would lead to spiritual ascent, Dickinson viewed the flower, which had accrued meaning through its literary use, from a naturalist's eye. Persisting when other flowers are gone, the late-blooming gentian served as a metaphor for her entire poetic career - like the flower, she was willing, to paraphrase Bryant in "To the Fringed Gentian," to "wait late and come alone."

Recently, several critics have read Dickinson's poems as material artifacts rather than purely literary works, detached from their historical and cultural milieu. ${ }^{4}$ Ellen Louise Hart and Martha Nell Smith have explored Dickinson's manuscripts as a type of dramatic performance, in which the placement of the words on the page inflects new meaning. In her essay "Corollas of Autumn: Reading Franklin's Dickinson," Loeffelholz muses on the new variorum edition of Dick- 
inson's poems and its effects on our understanding of her work and its material embodiment, especially the editor's decision to separate literature from "artifact." She faults Franklin for not representing aspects of the poems he considers nonliterary - for example, the slant of the dashes, the type of paper, "the manuscript line breaks that break up more or less conventionally rhymed and metered stanzas" (55). For Loeffelholz, who, at the time, was mounting an exhibit of Dickinson's manuscripts and ephemera at the Houghton Library, deciding which poems to place next to which material objects helped to resituate the texts in her mind as artifacts, documents, and material art. Rather than consider Dickinson's poems only in dialogue with other texts, as she had previously done, she saw them as made things. Thinking about the poem "The Gentian has a parched Corolla," Loeffelholz comments that "setting this poem beside the herbarium [that Dickinson made as a girl], [she] read it not only as an autumnal observation (of which Dickinson of course wrote many) but, more speculatively, as a retrospective examination of her own career as a writer, in several senses" (60). Examining Dickinson's botanical textbooks more fully and comparing her use of the gentian to those of her contemporaries illustrates this parallel between preserving flowers and writing.

\section{The Botanical Tradition}

Popular nineteenth-century botanical writings offered models of scientific analysis and instructed their readers in the means to select and preserve flowers for their own collections. At the same time, their artistic and creative impulse might have captured the imagination of a young poet, who herself created a herbarium as a girl. Dickinson's exposure to the popular botanical tradition is evident from two books in her family library: Edward Hitchcock's Catalogue of Plants Growing Without Cultivation in the Vicinity of Amherst College (1829) and Mrs. C. M. Badger's Wild Flowers Drawn and Colored From Nature (1859). ${ }^{5}$ Hitchcock's book lists the indigenous plants in the area of Amherst and includes Latin and common English names; he notes that through this volume his audience of young gentlemen "may have a pretty complete list of the plants growing in their vicinity," and further it "may serve as a very convenient index to an Herbarium" (iii). Although her volume is more selective and artistic, with its elaborate hand-colored illustrations of flowers and common associations of floral meanings, Badger's Wild Flowers enforces the emblematic nature of flowers. In addition, Dickinson's botanical textbooks, Familiar Lectures on Botany (1829) by Mrs. Almira Lincoln (Phelps) 
and The Class-Book of Botany (1854) by Alphonso Wood, familiar from her days at Mount Holyoke seminary and Amherst Academy, provide a systematic study of plants as well as instruction in collecting and preserving flowers. These studies assume a Christian worldview that seeks to demonstrate the existence of deity, and they find evidence of such creation in the vast and intricate variety of natural phenomena. While Dickinson might have questioned their deductions about the origin of life, she drew from their pages both a technical vocabulary and a description of bookmaking that influenced her literary production.

Alphonso Wood's A Class-Book of Botany (1854) provided a systematic study of plants and flowers, from which Dickinson probably gained her understanding of their morphology. In his chapter, "The Flower," Wood identifies calyx as "cup" (45) and corolla as "a chaplet or crown" (47), terms Dickinson adopts in her poems. Particularly interesting for its resonance with Dickinson's method of copying out her poems is Wood's description of how properly to collect and identify plants in a hortus siccus, or herbarium. In "Of Collecting and Preserving Plants," Wood explains the process using items that could also have comprised the mechanics of printing: a tin box, portable press, smooth, bibulous (blotting) paper, a small screw press, and weights, among other items (453). Once the flowers are selected and dried, they should be ordered, according to Wood, by type; identified and labeled; then "fastened to a sheet of firm white paper . . . either by glue or with loops of paper of the same kind, or they may be stitched to the paper with a fine needle" (120). Indeed, he advises the reader to categorize the specimens, and "Thus arranged, the orders are to be laid away upon the shelves of a cabinet, or packed in a chest" (120). Could Dickinson have had the hortus siccus in mind when she prepared her fascicles, with their orderly arrangement? Might she have considered Wood's injunction to arrange the flowers either "fastened to a sheet of firm white paper" or "stitched to the paper with a fine needle" in selecting and preserving her poems, which were then laid away in her bureau drawer?

Lincoln provides another striking parallel between poetry and material objects in her assertion that a study of nature leads to a greater appreciation of spiritual life. She instructs the reader to procure a blank book for preserving dried specimens and to affix the flowers to the paper with glue or by loops cut through the paper, offering further advice about the book's appearance ("white paper gives the plants a more showy appearance"), size ("A quarto size is more convenient than a larger one"), and design ("By the sides of the plants should be written the class, order, generic, and specific name" [43]). Dickinson might have drawn the idea of 
presenting her poems as floral "specimens" or including found objects in her letters from Lincoln and Wood - especially her habit of interlacing a ribbon through stationery to hold a flower or leaf. ${ }^{6}$ In writing to Abiah Root in 1845, she sends a geranium leaf for her to press and asks, "Have you made you an herbarium yet? I hope you will if you have not, it would be such a treasure to you" (L6). Later, in 1853, she writes to her friend Henry Emmons in response to a previous letter, referring to his "beautiful acknowledgment, far brighter than my flowers; and while with pleasure I lend you the little manuscript, I shall beg leave to claim it, when you again return" (L121). Since the two had exchanged books on occasion, she might have presented him with a grouping of poems - "flowers" - in manuscript and notes in a previous letter that she "arranged" for him (L119). Whether or not the poems were assembled as a book, the poet's early intention to give order and design to her work is evident in her assembling of poems for his perusal.

As the sister of the educator Emma Willard and the second woman elected to the American Association for the Advancement of Science, Lincoln was a serious and talented botanical writer whose dedication to careful observation of nature coexisted with her commitment to spiritual life. Her volume might also have partially inspired Dickinson's references to plants, lands, and mountains, as it was among her favorite textbooks (Sewall 357; Lowenberg 70). The frontispiece depicts a map of Chimborazo, a volcano in Ecuador, suggesting the book's importance for the emerging poet's interest in topography. Placed on a grid that measures in feet its distance from sea level to summit, the drawing of the mountain range and volcano describes the types of vegetation growing at different latitudes on the mountain. For Lincoln, studying volcanoes like Chimborazo offers evidence of a divine creator who designed the universe with an orderly plan and endowed human beings with rationality; although some are blind to its meanings, others will recognize its spiritual design. "The study of Botany," she concludes, "naturally leads to a greater love and reverence for the Deity" (14). Lincoln betrays a missionary zeal: "The Deity has not only placed before us an almost infinite variety of objects; but he has given to our minds the power of reducing the natural world into classes, so as to form beautiful and regular systems, by which we can comprehend, under a few terms, this vast number of individual things, which, without a system, would present to our bewildered minds a confused and indiscriminate mass" (11). As is evident from her dedication of the volume to her mother, for whom the world "has almost vanished from her sight in the brighter visions of eternity" (iii), Lincoln believes that studying plants will lead her primarily female readers to accept a 
Christian worldview that lies beyond the visible realm.

Lincoln classified the knowable world into two categories, Mind and Matter: on the one hand, Theology and Philosophy of the Human Mind; on the other, Natural Philosophy (physics), Chemistry, and Natural History. This final category is further subdivided into Zoology, Botany, and Mineralogy. Dickinson evidently considered such classification reductive, "superfluous" in the face of divinity:

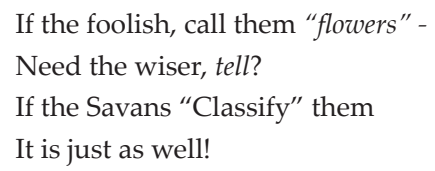

(Fr179, lines 1-4)

Placing herself among those of the "glad Belles lettres" (Fr179, line 17) who observe rather than dissect nature, she assumes a lowly role as a poet who will admire creation and divinity as scientists continue to compartmentalize it.

Lincoln frequently makes asides that praise botany as a field of study for, and as part of, the socialization of elite young women. She encourages them to search for plants "as a healthful and agreeable exercise," even though she enjoins them to leave more obscure samples to be retrieved by the "hardier sex." They should "be content to obtain specimens, without seeing them in their native wilds" (44). On the other hand, observing creatures outside of their natural setting implies a search for an invisible essence, not available to the eyes alone. For Lincoln, botanical study strengthens the mind's ability to discern meanings, including those not based on mere physical evidence: "you will find your minds gradually strengthened, and more competent to compare and judge in abstract studies, where the subjects of investigation are in the mind only, and cannot, like the plants, be looked at with the eyes, and handled with the hands" (45).

While she rejected the proper social behavior in which these botanical treatises instructed women, Dickinson adapted their lessons about the natural world to comment acutely on the absence of her family and friends. Much as the words culture and cultivation refer to the language of self-improvement as well as the management of plants, Domhnall Mitchell argues that Dickinson viewed gardening as a distinctly feminine task and part of the leisured life to which she was heir (113). Indeed, presenting flowers and books about flowers to another person forms a "shared culture of exchange" (112), especially among women, and several of the features that allowed Dickinson to participate in this culture are her literacy, her 
comparative leisure, and the effects of technology, such as the Franklin stove that allowed her to grow houseplants, a fairly recent nineteenth-century innovation. Dickinson referred frequently to flowers in her letters, often facetiously relating them to the absence of a loved one, and took great pride in her garden. In an 1851 letter remonstrating with her brother Austin for his absence from home, she notes how lonely his room is and jokes, "I am going to set out Crickets as soon as I find time that they by their shrill singing shall help disperse the gloom - will they grow if I transplant them?" (L 43). Her comment self-consciously calls attention to his absence - as the crickets sing, the absence is less evident. At the same time, she wittily would like to bring the natural world into Austin's room and imaginatively transforms the insects into plants, which might multiply to allay her loneliness. She ironically deploys flowers, insects, and other natural creatures to express her wish that she could control life as she would hope to plant and tend a garden - another aspect of her middle-class sensibility.

In her discussion of Dickinson's herbarium, now preserved at the Houghton Rare Book Library, Judith Farr notes its "genuinely artistic quality, derived from the appealing placement of the floral specimens and from their loveliness" (97). The dried flowers are meticulously labeled, revealing the poet's knowledge of their Latinate origins as well as her fondness for the exotic bloom along with more domestic varieties. While the habit of cultivating, arranging, and presenting flowers are typical pursuits of the leisured middle-class woman, Dickinson showed her affinity for common blooms and their artistic placement in the herbarium forecasts their later importance in her poetry. In selecting, among many others, a wide variety of small wildflowers - daisies, pansies, violets, crocuses, and anemones - she reveled in plants often overlooked by the casual observer. Lincoln notes that wildflowers give pleasure as a result of their unplanned discovery: "The love of native wildflowers is no doubt greatly heightened by the habit of seeking them out, and observing them in their peculiar situations; a Botanist will often, at the discovery of some lowly plant, growing by the side of a brook, or almost concealed in the cleft of a rock, experience a more vivid delight than could be produced by a view of the most splendid exotic" (44). Lincoln's passage echoes the poet's fondness for the lowly arbutus in the poem "Pink - small - and punctual" (Fr1357) that appears femininely "Covert" until, finally emerging "Bedecked" with bloom, "Nature forswears / Antiquity." Dickinson amassed different varieties of flowers in her conservatory to "distill" (Fr446) their generic meanings, to "comprehend" (Fr112) within a single "nectar" (Fr112) their multiple significances in her "Garden 
in the Brain " (Fr370). Early on, her book of pressed flowers marks her as an artist, a maker, and the gentian is significant for its literary resonance and its place in her canon.

\section{The Gentian}

Bryant's and Whittier's poems act as a backdrop both to Dickinson's revision of the portrayal of women as flowers and her concerns about spiritual life. Written in 1829, Bryant's “To the Fringed Gentian" appeared in an 1861 issue of the Springfield Republican, but the poem was already available to her in her family's copy of Bryant's Poems (1849). As a flower that often survived the first snowfall, the gentian often conveys the hope for life beyond death. The significance of the gentian for Dickinson might also have been gleaned from her books: her father gave her Mrs. Clarissa Munger Badger's Wild Flowers of America (1859), which contained a handpainted picture of the gentian. Dickinson or another person marked Bryant's "To the Fringed Gentian" with an x in the volume of his poems in her family library. This poem makes an analogy between the arrival of autumn and the poet's own death, but implies that his faith, like the gentian's appearance, will insure his salvation :

Thou blossom bright with autumn dew

And colored with the heaven's own blue,

That openest when the quiet light

Succeeds the keen and frosty night -

Thou comest not when violets lean

O'er wandering brooks and springs unseen,

Or columbines, in purple dressed,

Nod o'er the ground-bird's hidden nest.

Thou waitest late and com'st alone,

When woods are bare and birds are flown,

And frosts and shortening days portend

The aged year is at his end.

Then doth thy sweet and quiet eye

Look through its fringes to the sky.

Blue - blue - as if that sky let fall 
A flower from its cerulean wall.

I would that thus, when I shall see

The hour of death draw near to me,

Hope, blossoming within my heart,

May look to heaven as I depart.

(Bryant, Poetical Works 128)

Bryant links the gentian's tardy appearance with his own sense of mortality. He distinguishes it from other flowers: rather than arrive in spring, "when violets lean / O'er wandering brooks and springs unseen" (with "unseen" implying ambiguously that the violets rather than the "springs" might be hidden from viewers who overlook their significance) or "columbines, in purple dressed, / Nod o'er the ground-bird's hidden nest," the gentian comes in fall, when little else does. As Loeffelholz notes, Bryant's poem captures the tendency among his counterparts to identify femininity both with the maternal (the columbine's bending over "the ground-bird's hidden nest") and the narcissistic (the violet's gazing into the "brooks and springs unseen") (63). The socially codified meanings of these flowers suggest the traditional female life cycle, but they also reflect Bryant's sense of a correspondence between the natural and the divine. Taking his lesson from the gentian, Bryant compares its "sweet and quiet eye" - its center and perhaps a pun on "I" - as it opens to the light to the poet's eye, predicting his own turn to heaven for consolation at the poem's end. Much as the flower mirrors its celestial origins (since "heaven's own blue" reappears in the blue of the flower), the poem links the poet's interior state of mind and its exterior manifestation. Resembling an eye both in its shape, with fringes like eyelashes, and color, the flower acts as an exemplum to the speaker, who finds in the earthly gentian proof of a corresponding heavenly flower that the sky has let fall "from its cerulean wall"(16); hence, the flower offers a hint of mercy from the cold inevitability of death. As the poem draws to its close, the line "Hope, blossoming within my heart" implies that the speaker identifies with the flower and has internalized its message. ${ }^{7}$ Such didactic emblem-reading would have raised questions for Dickinson, who observed nature less sentimentally but shared Bryant's occasional difficulty in resolving anxiety about an uncertain afterlife. ${ }^{8}$

To take another example of such emblematic readings of nature, John Greenleaf Whittier's "The Pressed Gentian," first published in St. Nicholas Magazine in 1876, employs the gentian as a token of inner truth that directs the poet's gaze 
inward. At Christmastime, "the time of gifts," which signals the arrival of spiritual gifts for the speaker, a dried and preserved gentian hangs in his window within a "gray disk of clouded glass" (6) in sight of "wayside travelers." The poem contrasts their dull "outlook" with the insight engendered by the flower. The travelers overlook the dried flower's significance, yet it teaches the poet to see a correspondence between natural and spiritual worlds. First, it brings him in contact with a brighter nature than the cold landscape outside, as it "Turns from without its face of bloom / To the warm tropic of my room" (13-14); second, its "face of bloom" is as "fair as when beside its brook / The hue of bending skies it took" (13, 15-16), mirroring the color of fairer skies, transporting the energy of the sun to the speaker's inner world. In the third and fourth stanzas, comparing the flower to people who hide their true value - since the gentian conveys its "inward grace" to those whose "loving eyes" are likely to be receptive-and to "deeper meanings," the speaker asserts its value:

So from the trodden ways of earth,

Seem some sweet souls who veil their worth,

And offer to the careless glance

The clouding gray of circumstance.

They blossom best where hearth-fires burn,

To loving eyes alone they turn

The flowers of inward grace, that hide

Their beauty from the world outside.

But deeper meanings come to me, My half-immortal flower, from thee! Man judges from a partial view, None ever yet his brother knew; The Eternal Eye that sees the whole May better read the darkened soul, And find, to outward sense denied, The flower upon its inmost side.

(Waggoner 159, lines 9-24)

As an emblem, the modest, self-effacing gentian evolves over the course of the poem from a "token" of the "inward grace" of those "sweet souls" who hide their inner beauty to a "half-immortal" flower, which instructs the speaker in Christian values. He imagines that an "Eternal Eye" looking inside more truly than the gen- 
tian might understand the reasons for human beings' hidden natures better than we can.

Dickinson returned several times to this flower and its tendency to symbolize female humility and spiritual revelation. Parched, pressed, dried, their perfume extracted, and laid away in "Lady's Drawer" (Fr772, line 6), flowers suggest female bodies and their dress as well as acting as symbols of human mortality. Writing in 1859 to Dr. and Mrs. J. G. Holland, who had visited Amherst for a meeting of the American Association for the Advancement of Science, Dickinson dramatizes the impact of their absence through the analogy of flowers:

The gentian is a greedy flower, and overtakes us all. Indeed, this world is short, and I wish, until I tremble, to touch the ones I love before the hills are red - are gray - are white - are "born again"! If we knew how deep the crocus lay, we never should let go. Still, crocuses stud many mounds whose gardeners till in anguish some tiny, vanished bulb. (L207)

A tour de force, this letter wittily expresses her desire to displace the actual culprit - time - with the gentian, and then anticipates and reconciles the absence of her friends as part of a natural cycle through the analogy to flowers. As a harbinger of the fall, the gentian reminds the speaker of the inevitable decline of life. Her attachment to her friends - captured in the fervent desire to "touch" them "until I tremble" - is evident, as she anticipates the fields changing colors in autumn and winter. She fantasizes about their disappearance in the earth, much as the "crocus" is planted in fall and reappears every spring. The Calvinist language of death and redemption - the fields are "born again," and their gardeners till them "in anguish" till the "vanished" reappears - aptly sums up the fear inherent in the speaker's wish to believe in the resurrection. As we saw earlier in her letter to Austin, however, her appeal to her friends operates through a power fantasy that allows the speaker imaginatively to detach from a situation over which she has no real control. Whereas Bryant and Whittier assume the gentian as a spiritual guide, Dickinson aligns the flower with the passage of time that she cannot fully reconcile with the promise of salvation.

In "It will be Summer - eventually" (Fr374), Dickinson archly comments on the promise of salvation by aligning the appearance of flowers, their "everlasting fashion," with the certainty of an afterlife. Having addressed another shorter version of the poem to Samuel Bowles in 1862, Dickinson copied the poem into fascicle 18 with other poems that dispute salvation. ${ }^{9}$ Although the phrase "Covenant 
Gentians" (which appears twice in her poems) underscores her apparent faith, she also undercuts the promise of an afterlife:

The Wild Rose - redden in the Bog -

The Aster - on the Hill

Her everlasting fashion - set -

And Covenant Gentians - frill -

Till Summer folds her miracle -

As Women - do - their Gown -

Or Priests - adjust the Symbols -

When Sacrament - is done -

(Fr 374, lines 13-20)

The recurrent beauty of summer reflects the hope for salvation, yet our hope is undercut by the withdrawal of beauty in winter. In referring to the "frill" of gentians, Dickinson alludes not only to their appearance at the end of the season, but to the decorative edging on a woman's dress. Such a reference implies that the changeableness of human life, our fickle attachment to every passing trend, stands in stark contrast to nature's "everlasting fashion." And yet, in relating the close of summer's "miracle" to a merely domestic chore, the speaker divests it of any religious or spiritual significance: the "Symbols" of the mass, its bread and wine, serve as reminders of Christ's body and blood, but they are devoid of actual significance, empty as are the plate and chalice when put away after the ritual. The real miracle of creation and transformation takes place in everyday nature, rather than in an afterlife symbolized by the mass.

In "God made a little Gentian" (Fr520), Dickinson transforms the flower from a harbinger of the divine into a metaphor for self-willed artistry. If this lyric was written, according to Franklin, at a period of intense activity around 1863 and shortly before she gave up binding the fascicles, then surely the poet also shows self-determination, a more mature response to the problem of literary influence that she had already confronted with "The Gentian weaves her fringes" (Fr21) in 1858. Having "failed" to come early, the gentian distinguishes the poet's desire to become a writer against more traditional female roles: "It tried - to be a Rose -" (Fr520, line 2). In contrast to the "Rose," with its associations of youth and female sexuality, the gentian forsakes its fabled humility to become instead a siren, a "Purple Creature" that "ravished" the hillside. Dickinson's flower stubbornly 
holds back until the frosts come as her "condition" for growth and will not bloom unless the "North" invokes her, claiming for herself the power originally given to God as the maker. Spoken in the first person, the last line aligns the speaker closely with the gentian, who invokes God in a way that ironically maintains the fiction of obedience, while she demands subservience: "Creator - Shall I - bloom?"

Written around 1858, several years before she appropriates the gentian's lateblooming grandeur in "God made a little Gentian" (Fr520), "The Gentian weaves her fringes" (Fr21) parodies Bryant's "To the Fringed Gentian." In this highly redacted response to his poem, Dickinson satirizes Bryant's willingness to evoke nature as a conduit to spiritual revelation:

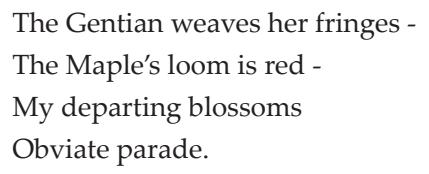

In this mock elegy, Dickinson undercuts the possibility of a moral, Christian pronouncement about the end of summer by denying the mourner a pompous funeral or "parade." The textile metaphors, "weaves" and "loom," as well as the idea that the fall leaves may be read as a tapestry imply a covert critique of the emblematic style of her contemporaries. If her blossoms leave without fanfare, if they eliminate the need for pomp and ceremony, does that put nature's commemoration in question? Or does it instead imply that nature, when witnessed and observed directly, does not need or warrant the poetic flights of Bryant and his contemporaries? Finally, her terse, almost peremptory style preempts the desire to draw moral or spiritual conclusions about human life based on natural tropes .

Another early poem, "Besides the autumn poets sing" (Fr123), which Franklin judges was written in 1859, takes other poets to task for misapprehending the turning point of autumn and reclaims its pagan origins. Since another version was sent to Susan Gilbert Dickinson, it might form part of an exchange the two women shared about Bryant's poetry and express her amusement at the literary style of Bryant and James Thomson, author of The Seasons:

Besides the Autumn poets sing

A few prosaic days

A little this side of the snow 
And that side of the Haze -

A few incisive mornings -

A few Ascetic eves -

Gone - Mr. Bryant's "Golden Rod" -

And Mr. Thomson's "sheaves."

(Fr123B, lines 1-8)

The opening line encourages the reader to pause after "Autumn," implying perhaps that fall more eloquently announces the season than these poets. If we reverse the initial pair of adjectives - "Autumn" and "prosaic" - and assume, as logic would seem to dictate, that "Autumn" refers to days, then, is Dickinson saying that Bryant and Thomson are "prosaic" poets, both in their use of blank verse and in their inept descriptions of autumnal landscape? Can the autumn days more appropriately "sing" than these poets? In that sense, Dickinson may be more attentive to the "prosaic" side of the season overlooked by her contemporaries, just after the colors of fall have passed and before the winter arrives.

Popular botanical essays she would have read, in addition to Bryant and Thomson, American and Scottish poets who had famously memorialized the season, further amplify Dickinson's stylistic critique. A brief survey of the 1862 Atlantic Monthly suggests that in naturalist writing, such as Thomas Wentworth Higginson's "The Profession of Flowers" and Henry David Thoreau's "Autumnal Tints" and "Wild Apples," investigation and nostalgia are complementary ways of understanding the natural world. Thoreau's "Autumnal Tints" contrasts the bright hues of American forests with the darker, more somber tones of English woods, as reflected in Thomson's poems, concluding "the autumnal change of our woods has not made a deep impression on our own literature yet. October has hardly tinged our poetry" (Thoreau 385). Dickinson probably responded more favorably to Thoreau's painterly comparison between falling leaves and human death than to Thomson and Bryant's more sanguine emphasis on the rich fields and the glittering, prattling streams, signs of nature's plenitude. Thomson's section on autumn begins by crowning the speaker who is personified as autumn: "Crowned with the sickle and the wheaten sheaf / While Autumn nodding o'er the yellow plain / Comes jovial on, the Doric reed once more / Well-pleased I tune" (Thomson 133, lines 1-4). Similarly, in Bryant's "Autumn Woods" the rustling stream evokes the change of seasons: "The rivulet, late unseen, / Where bickering through the shrubs its waters run, / Shines with the image of its golden screen, 
/ And glimmerings of the sun" (Bryant, Poetical Works 69, lines 29-32). Bryant's "The Death of Flowers" provides a more direct source for Dickinson's allusion:

The wind-flower and the violet, they perished long ago,

And the brier-rose and the orchis died amid the summer glow;

But on the hills the golden-rod, and the aster in the wood,

And the yellow sun-flower by the brook in the autumn beauty stood

(Bryant, Poetical Works 93, lines 13-16)

While Bryant and Thomson emphasize the lively continuation of nature, Dickinson exposes the transitional moment between fall and winter, when stillness and death are most evident.

In making these literary allusions as well as the textual pun in "sheaves," Dickinson appears to reject the high-flown style of poets like Bryant and Thomson, who cannot compete with her more compelling vision of nature. She continues:

\author{
Still, is the bustle in the Brook - \\ Sealed are the spicy valves - \\ Mesmeric fingers softly touch \\ The eyes of many Elves - \\ Perhaps a squirrel may remain - \\ My sentiments to share - \\ Grant me, Oh Lord, a sunny mind - \\ Thy windy will to bear!
}

12 Elves - ] the dash made from a period

(Fr123B, lines 9-16)

Several images in Dickinson's poem echo Bryant's, but her poem emphasizes nature's inscrutability. For Dickinson, nature retains its secrets and is populated by pagan and magical "Elves." While Bryant chooses to read death in nature allegorically as foretelling the end of human life, Dickinson portrays the "Brook" as still, unyielding, quiet, even secretive. Already a cliché by the 1850s, the babbling brook may have resonated for her as part of a literary language she found hackneyed. The possible echo of "book" in "brook" hearkens back to the "sheaves" of Thomson and implies that his and Bryant's poems are contrary to the workings of nature, which is "sealed" to prying eyes. As small streams, brooks may repre- 
sent a diminished intellectual and creative force for Dickinson, who more often associates creative or imaginative power with the sea. Rather than a transparent medium, nature has the power to conceal its inner workings, leaving the speaker to ask for the strength or perspective to withstand God's "windy will" and the vagaries of nature.

Developing a series of analogies that describe the feeling of distance between the wish and its fulfillment, "Distrustful of the Gentian" (Fr26) and "Flees so the phantom meadow" (Fr27) provide a critique of the ease with which we draw moral conclusions about human life. ${ }^{10}$ Perhaps skeptical of the faith that the gentian represents and the ascent to heaven predicted in Bryant's poem, the speaker of the first poem turns away from the flower, only to be reminded of her "perfidy" (Fr26) when it does blossom. Unexpectedly, the gentian's arrival confronts the speaker who has resigned herself to loss, and her deliberate breach of faith seems to disappear when the gentian returns. Yet the absence of a friend renews her sense of loss, which she redresses through "singing" - perhaps, as she tells us elsewhere, "as the Boy does by the Burying ground - because I am afraid" (L261). Similarly, "Flees so the phantom meadow" (Fr27) echoes the mirage that a dying person envisions. Indeed, a number of echoes from Bryant's poem might recur - the "brooks" beside which the gentian grows, the "evening spires" (Fr27) that might resemble Bryant's "cerulean wall," and "Heaven," which the flower regards in "To a Fringed Gentian." But unlike Bryant's speaker, who looks to heaven for consolation, such long-anticipated promises for Dickinson's speaker are always just out of reach - like the hand in a "phantom meadow" (Fr27) that reaches for a "so distant Heaven." (Fr27).

Finally, the radical compression of language, irregularity of stanza structure (she has left the quatrain behind), and highly compact imagery of the late lyric that begins "The Gentian has a parched Corolla" (Fr1458), imply that for her the gentian has transcended its early interpretation. Whereas earlier Dickinson used the gentian to satirize the unproblematic correspondence between nature and spirit among her poetic contemporaries, it later represents the evolution of her literary career. Written about 1877, this poem extends Dickinson's earlier critique of her contemporaries' poems into a metaphor for greatness:

The Gentian has a parched Corolla -

Like Azure dried

'Tis Nature's buoyant juices

Beatified - 


\begin{abstract}
Without a vaunt or sheen
As casual as Rain

And as benign -

When most is past - it comes -

Nor isolate it seems -

It's Bond it's Friend -

To fill it's Fringed career

And aid an aged Year

Abundant end -

It's lot - were it forgot -

This truth endear -

Fidelity is gain

Creation o'er -

6 casual] odorless - / innocent 11 career] sphere

13] A fervent end - / [A] loyal [end - ] / [A] gracious [end - ] / an ample [end] - 15 endear] declare
\end{abstract}

(Fr1458)

Like Whittier's pressed flower, "Azure dried" refers to the intensification of the flower's scent and color as a result of its aging. It also evokes the herbarium, with its observation and careful, clinical examination, to preserve specimens and deny the ephemeral. "Parched Corolla," with its botanical description of an array of petals, recalls the technical language of Lincoln's botanical handbook as well as the elevation of a crown. Loeffelholz surmises that the casual presentation of this poem might imply that the poet had left off the exacting work of ordering and identifying the poems in the fascicles (64). Franklin notes that this poem was pinned to a piece of stationery from Austin addressed "To the Old Folks at home" and humorously suggesting a menu for a dinner (Franklin variorum 1278). We might also argue of course that the "buoyant juices" refer to digestion; and several other poems that Franklin dates from this period appear to have been jotted down on grocery lists, scraps of paper, and brief notes concerning social dates. ${ }^{11}$ If Dickinson meant to respond to Austin's joke that she and her sister were "old folks," she does so by triumphantly asserting the power implied in aging .

In contrast to Bryant's poetry as a symbol of spiritual life, Dickinson finds consolation not through religion but through deliberate artistry. Here she refrains from identifying the gentian's sex, perhaps rejecting the tendency among Bryant 
and other poets to conflate flowers with stereotypical feminine characteristics (Loeffelholz 63). Rather, the word "Beatified," usually reserved for saints, suggests that death and spiritual glorification arise from the ordinary processes of nature. ${ }^{12}$ With its fabled humility, the gentian presents itself to the world without disguise or boastful "vaunt"; its death is not "isolate" but typical. The "sheen" may refer to rain, now evaporated, and to the seasonal cycle, alluded to in "as casual as Rain" (Dickinson provides "innocent" as a variant for "casual," implying that the gentian has retained its integrity, despite the passage of years). Exploiting internal and external rhyme, she highlights the flower's self-dependence and faithful fulfillment of its promise to bloom. With its late arrival, the gentian bears witness to the continuation of all life; it consoles the speaker who is growing older and whose work may perhaps be forgotten, as Dickinson might well have feared, with its promise of an "Abundant end" to a "Fringed career." "It's Bond it's Friend," like the "Covenant Gentians" (Fr374) of her earlier poems, suggests in the flower's "Fidelity" to the truth that rewards come to those who live long and humbly, and that this knowledge will sustain the speaker from despair.

In reappearing late in her oeuvre and as a reflection of her entire poetic "career," Dickinson's gentian holds out the promise that her fidelity to her conception of poetry might outweigh its potential disappearance for future generations of readers. The concluding line, "Creation o'er," might refer in a normative Christian reading to the faith that comes as a result of the "happy fall" or Felix culpa following the creation in the Book of Genesis. Or "Creation o'er" might pun on the fact that the poem has just ended. Although Dickinson had long before given up the binding of her fascicles, in 1864, her literary production had continued as sets but without the same attempt at book-making. As a commentary on her literary career, the gentian compensates her with its "fidelity" for any loss she may have sustained in life and pays tribute to her own faithfulness to the original design of her poetry.

A floral compendium of Dickinson's poems cannot ignore the gentian, for her adherence to this flower - as I have sketched here - signals both her sensitivity to the changing landscape in Amherst and to the works of her contemporaries. Referring to the literary flowers of Bryant and Whittier, Dickinson's gentian poems do not see the natural world as symbolic of human morality, but instead interpret the flower as a sign of nature's inscrutability and the poet's own evolving literary career. With its textual implications, the fringed gentian allows the poet to comment on her literary contemporaries and employ her clinical observation 
of nature, filtered through her education and subjected to her own design. In "Within my Garden, rides a Bird" (Fr370), Dickinson refers in a variant phrase to a hummingbird's flight as a "Microscopic Gig." Such "microscopic" views of nature came as a result of her botanical training, and they enrich the reader with the many meanings inhering in this single flower.

\section{Notes}

I would like to thank Eliza Richards for generously offering comments at an early stage in the writing of this essay.

1. The Fringed Gentian, illus. Lambert Hollis (Troy, NY: H. B. Nims \& Co., 1884).

2. George Monteiro and Barton St. Armand provide a substantial revision of the poet's work through their discussion of her pictorial sources in the emblem tradition as well as some of their prose explications of emblems she knew. Emblems she saw, in works such as Peter Parley's Book of Fables (1834) and William Holmes and John W. Barber's Religious Emblems (1834) and Religious Allegories (1848), were specifically religious. Part of a larger tradition of secular literature, flowers carry meanings for Dickinson and her contemporaries that were religious and socially codified.

3. A third poem, "God made a little Gentian," appears in Fascicle 24. It accompanies two other poems, "Unto my Books - so good to turn" and "The Spider holds a Silver Ball," both of which reflect directly or indirectly on the process of reading or writing.

4. In Open Me Carefully: Emily Dickinson's Intimate Letters to Susan Huntington Dickinson, Ellen Louise Hart and Martha Nell Smith provide a sustained reading of Dickinson's poems as emanating from the compositional process she shared with her sister-inlaw, Susan Gilbert Huntington Dickinson. In a more metaphysical reading, Virginia Jackson explores the ontological split between self and its representation within the construction of the subject - a division that she argues cannot be redressed simply by examining the poet's handwriting. Other critics, such as Judith Farr and Paula Bennett, contend that Dickinson's imagery derives from the tradition of female labor and the domestic work, such as textile manufacture and gardening, that links her to other female writers. I have also contended that she uses flowers as a form of cultural exchange, primarily among women. See Hart and Smith, 63-65; Jackson, 102-103; Farr, esp. 13-74 and passim; Bennett, 221-228; and Petrino, 140-144.

5. Mrs. C. M. Badger, Wild Flowers Drawn and Colored From Nature, intro. Lydia Sigourney (New York: Charles Scribner, 1859). Badger's text will hereafter be referred to as Wild Flowers.

6. Sewall believes her habit of sending flowers to friends, accompanied by poems, was "certainly encouraged by her studies in school" (Sewall, "Science" 21). He counts thirty-three such poems, dated roughly from 1858 to 1884 (Sewall, "Science" 21).

7. Farr notes that Bryant employs a "somewhat confused analogy" (115) in this line, but I argue that it is precisely his insecurity about the existence of an afterlife, reflected in the gentian that mirrors the heavens, that causes this problem. The syntactical ambiguity of this line contradicts or at least qualifies the speaker's long-awaited anticipation of the event.

8. In a notable exception to the readings of other critics, in "New England Poetics: 
Emerson, Dickinson, and Others," Lawrence Buell argues that, read as part of the poetic tradition from the revolution to the Civil War, the "experimentalism of Emerson and Dickinson is seen as being not so much a dissent from the poetic norms created by mainstream poetry as a creative elaboration of those norms" (107).

9. Among the poems included in this fascicle are "He strained my faith -" (Fr366), "Those fair - fictitious people -" (Fr369), and "This World is not conclusion." (Fr373).

10. The composition of both poems (or their copying) into fascicle 1 may have been in short succession, suggesting that the poems were linked in the poet's mind.

11. A survey of the poems dating from 1877 in Franklin's edition reveals that the poet wrote several times on paper that made references to food: "Lunch for Tizzie" appears on the paper with "Summer has two Beginnings" (Fr1457); "Corn" and "Wheat" on stationery with "She laid her docile Crescent down" (Fr1453A); and "Ice Cream" on a piece of stationery with "How Human Nature dotes" (Fr1440).

12. For another suggestive reading of "The Gentian has a parched Corolla" in the context of other poems about Indian summer, see Adam Sweeting, esp. 147-152. Although he contends that the consolation promised by the gentian is "a purposeless return to life" (149), one could also argue that Dickinson's gentian poems reflect a renewal of life-her sense of fulfillment as a result of writing poetry, regardless of whether or not it would be recognized in print.

\section{Works Cited}

The following abbreviations are used to refer to the writings of Emily Dickinson:

Fr The Poems of Emily Dickinson. ed. R.W. Franklin. 3 vols. Cambridge, MA: Harvard UP, 1998. Citation by poem number.

J The Poems of Emily Dickinson. ed. Thomas H. Johnson. 3 vols. Cambridge, MA: Harvard UP, 1955. Citation by poem number.

L The Letters of Emily Dickinson. ed. Thomas H. Johnson and Theodora Ward. 3 vols. Cambridge, MA: Harvard UP, 1958. Citation by letter number.

Badger, Mrs. C. M. Wild Flowers Drawn and Colored from Nature. Introd. L. H. Sigourney. New York: Charles Scribner, 1859.

Bennett, Paula Bernat. "Emily Dickinson and Her American Women Poet Peers." In The Cambridge Companion to Emily Dickinson, edited by Wendy Martin, 215-35. Cambridge: Cambridge University Press, 2002.

Bryant, William Cullen. "The Fringed Gentian.” Illustrated by Lambert Hollis. Troy, NY: H.B. Nims \& Co., 1884. . The Poetical Works of William Cullen Bryant. New York: AMS Press, 1969.

Buell, Lawrence. New England Literary Culture: From Revolution through Renaissance. Cambridge: Cambridge University Press, 1986.

Farr, Judith. The Gardens of Emily Dickinson. Cambridge: Harvard UP, 2004. 
Hart, Ellen Louise, and Martha Nell Smith, eds. Open Me Carefully: Emily Dickinson's Intimate Letters to Susan Huntington Dickinson. Ashfield, MA.: Paris Press, 1998.

Higginson, Thomas Wentworth. "The Procession of the Flowers." Atlantic Monthly 10.62 (1862): 647-657.

Hitchcock, Edward. Prefatory. Catalogue of Plants Growing Without Cultivation in the Vicinity of Amherst College. Amherst: J.S. and C. Adams, and Co., 1829.

Jackson, Virginia L. "'Faith in Anatomy': Reading Emily Dickinson." In Dwelling in Possibility: Women Poets and Critics on Poetry, edited by Yopie Prins and Maeera Shreiber, 85-108. Ithaca: Cornell University Press, 1997.

Lincoln, Almira H. Familiar Lectures on Botany. Including Practical and Elementary Botany with Generic and Specific Descriptions of the Most Common Native and Foreign Plants and A Vocabulary of Botanical Terms for the Use of Higher Schools and Academies. Hartford: H. and F. J. Huntington, 1829.

Loeffelholz, Mary. “Corollas of Autumn: Reading Franklin's Dickinson." The Emily Dickinson Journal 8.2 (1999): 55-71.

Lowenberg, Carlton, Lowenberg, Territa A., and Carla L. Brown, eds. Emily Dickinson's Textbooks. Layfayette, CA: C. Lowenberg, 1986.

Mitchell, Domhnall. Emily Dickinson: Monarch of Perception. Amherst: University of Massachusetts Press, 2000.

Monteiro, George, and Barton Levi St. Armand. "The Experienced Emblem: A Study of the Poetry of Emily Dickinson." Prospects: The Annual of American Cultural Studies. New York: Burt Franklin \& Company, 1981.

Osgood, Frances Sargent. Poetry of Flowers, and Flowers of Poetry, To Which Are Added, A Simple Treatise on Botany, With Familiar Examples, and A Copious Floral Dictionary. New York: J. C. Riker, 1841.

Petrino, Elizabeth A. “'Silent Eloquence': The Social Codification of Floral Metaphors in the Poems of Frances Sargent Osgood and Emily Dickinson," Legacy: A Journal of American Women Writers 15 (1998): 139-57.

Rubin, Gayle. "The Traffic in Women: Notes on the 'Political Economy' of Sex." Toward an Anthropology of Women, ed. Rayna R. Reiter. New York: Monthly Review Press, 1975. 157-210.

Sewall, Richard B. The Life of Emily Dickinson. New York: Farrar, Straus \& Giroux, 1974.

_. "Science and the Poets: Emily Dickinson's Herbarium and 'The Clue Divine.'” Harvard Library Bulletin 3.1 (1992): 11-26.

Sweeting, Adam. Beneath the Second Sun: A Cultural History of Indian Summer. Hanover: University Press of New England, 2003.

Thomson, James. The Seasons. Philadelphia: Edwin T. Scott, 1828.

Thoreau, Henry David. “Autumnal Tints." Atlantic Monthly 10.60 (1862): 385-402. 
“Wild Apples." Atlantic Monthly 10.61 (1862): 513-526.

Waggoner, Hyatt, ed. The Poetical Works of Whittier. Boston: Houghton Mifflin Co., 1975.

Wood, Alphonso. A Class-Book of Botany, Designed for Colleges, Academies, and Other Seminaries, In Two Parts: Part. I. The Elements of Botanical Science, Part II. The Natural Orders, Illustrated by a Flora of the Northern, Middle, and Western States; Particularly of the United States North of the Capitol, Lat. 38 3/4 Degrees. Claremont, NH: Manufacturing Company, 1854. 